Brit. J. industr. Med., 1964, 21, 135.

\title{
EFFECTS OF ELECTRIC SHOCK ON RESPIRATION IN THE RABBIT*
}

\author{
BY \\ W. R. LEE and S. ZOLEDZIOWSKI \\ From the Nuffield Department of Occupational Health, University of Manchester, and the Department \\ of Electrical Engineering, Royal College of Advanced Technology, Salford
}

(RECEIVED FOR PUBLICATION NOVEMBER 12, 1963)

\begin{abstract}
Death from electric shock has been investigated on and off for just over 200 years. By the turn of the present century the three main methods of immediate death had been described. They are tetanic contraction of the respiratory muscles, ventricular fibrillation, and respiratory arrest. Since then there has been controversy over the relative importance of the last two as modes of death. For over half a century the first-aid treatment advised has been artificial respiration, based on the assumption that respiratory arrest is common in the usual limb to limb shock. The evidence for this assumption is reviewed and found to be open to question.

An experimental investigation of the effect of forelimb to forelimb electric shock on respiration in rabbits has shown that, with currents up to about $200 \mathrm{~mA}$, respiratory arrest appears to be due solely to muscular contraction. Larger currents produce respiratory arrest, usually followed by a delay before spontaneous resumption of respiration. The experimental currents have been taken up to 1 ampere, and at this level they resulted in considerable heating of the tissues. This resulted in marked macroscopic and histological changes in the forelimbs, despite which the animal breathed again spontaneously if ventricular fibrillation had not occurred.
\end{abstract}

\section{Introduction}

By the turn of the present century the three mechanisms of immediate death in electric shock had been worked out and were enumerated by Jex-Blake (1913), who gave a full review of the literature up to that time. These three processes are ventricular fibrillation, prolonged respiratory arrest after the shock (primary respiratory arrest), and asphyxia resulting from tetanic contraction of the respiratory muscles during the shock. The latter appears to be relatively uncommon, but there has been some dispute as to whether respiratory arrest or ventricular fibrillation, leading to circulatory arrest, is the more common (Jellinek, 1912; Boruttau, 1918; Legge et al., 1921; Jellinek, 1922; Ajello, 1929; Helpern and Strassmann, 1941). As long as there was no first-aid treatment for circulatory arrest, discussion on whether the common limb to limb shock caused primary respiratory arrest or circulatory arrest remained of theoretical interest, and the accepted first-aid treatment has been artificial respiration.

* Part of this study formed part of the material for a thesis submitted by one of us (W.R.L.) to the University of London.
However, the development of closed-chest cardiac massage by Kouwenhoven, Jude, and Knickerbocker (1960) brings practical importance to the question of the mechanism of death.

The evidence, in support of the statement that respiratory arrest is produced, has been critically reviewed elsewhere (Lee, 1963). Briefly, it includes studies of accident reports (Drinker, 1928; Maclachlan, 1930 and 1959; Ministry of Labour, 1955 and 1958), including the frequently cited case of a man revived after eight hours' artificial respiration (Maclachlan, 1930). It is perhaps not widely recognized that in this accident the current followed a pathway from forehead to limbs. This is an uncommon pathway in electrical accidents; more commonly, the current passes from a forelimb to another limb (Langworthy and Kouwenhoven, 1931; Kouwenhoven, Hooker, and Langworthy, 1932; Polson, 1959; Lee, 1961). Many experimenters have used a current pathway through the head (Urquhart, 1927; Urquhart and Noble, 1929; Langworthy and Kouwenhoven, 1930; Andreuzzi, 1959a, 1959b), but it is irrelevant to cite these when considering the common electrical accident. 
Langworthy and Kouwenhoven, working with rats in 1931, did use a limb to limb pathway, but the currents employed, about one ampere at 1,000 volts, were relatively large considering the small size of the animals. It is not surprising that they noted 'immediate coagulation of the protoplasm in the muscles of the forelegs and over the chest wall'. Even so, when the pathway used was right hind limb to left hind limb 'all the rats breathed at once following the opening of the switch'. The histological evidence of Langworthy (1930) was inconclusive.

On the other hand, in electroconvulsive therapy, when currents in the region of $300 \mathrm{~mA}$ (Fleming, Golla, and Walter, 1939) or more (Kouwenhoven, 1949) are passed between the temples of a human subject, respiratory arrest is extremely uncommon (Kalinowsky, 1959). Furthermore the tracings in the paper by Greenberg (1940) indicate that, following a shock of $50 \mathrm{~mA}$ for 10 seconds from forelimb to opposite hindlimb in dogs, respiration resumed immediately the current was switched off. Similar results are seen in the tracing by Robinovitch (1911), presented by Greenberg, and in Fig. 2 of the paper by Koeppen (1961).

From all these studies there emerges little positive evidence to support the hypothesis that respiratory arrest is the common cause of death in limb to limb shocks. This indicates a need for investigating the problem further.

Animal experiments would be of value for there is no reason to suppose that current distribution in a human body would be different from that in animals (Weeks, Alexander, and Dennis, 1939; Waller, 1889; Einthoven, Fahr, and de Waart, 1913; Nahum, 1955; Schwan, Kay, Bothwell, and Foltz, 1954; Pozzi, 1961). Furthermore, since the respiratory effects resulting from the passage of a strong electric current through the respiratory centre of the human (Maclachlan, 1930; Morikawa and Steichen, 1960) are comparable with those obtained in animals (Urquhart, 1927; Andreuzzi, 1959a), it is reasonable to assume that reactions to limb to limb shocks will be the same.

\section{Experimental Technique}

To separate the effects of electric shock on respiration from those due to ventricular fibrillation, an animal was chosen which frequently defibrillates spontaneously. The rabbit satisfied this condition and was chosen for this study.

Rabbits were anaesthetized with intravenous sodium pentobarbital (Nembutal, Abbot) dissolved in water to $20 \mathrm{mg}$. $/ \mathrm{ml}$. A tracheal cannula was tied in place and connected through rebreathing valves with a closed-circuit system containing carbon dioxide absorber and a Benedict-Roth spirometer, $6 \mathrm{~cm}$. internal diameter, together with means for admitting oxygen to the system when desired. The system was flushed with oxygen before connecting the animal to it. Inspiration produced an upward movement of the recorded trace.

The animal was given $0.3 \mathrm{ml}$. of heparin intravenously, and to record the blood pressure (B.P.) a mercury manometer was connected to a cannula inserted into a common carotid artery. Shock duration, time scale, and, as noted above, respiration were also recorded.

In the descriptions of the experiments time is counted from the instant of application of shock. This and the instant of current interruption are indicated on the respiration trace.

All shocks were applied from forelimb to forelimb. An area encircling the distal part of the forelimb just above the forepaws 1 to 1.5 in. wide was cleared of fur. To decrease contact resistance, a saline-soaked pad was placed around each area and was kept in position by an encircling copper band to which the current source was connected. A similar connexion was made to the right leg for the earth terminal of the electrocardiogram (E.C.G.). The saline pads were always kept moistened to keep the skin resistance low. Similar saline pads were also placed on bared areas in the praecordial region, one over the lower ribs and the other over the upper chest, and were connected to defibrillating electrodes.

The $240 \mathrm{~V}, 50 \mathrm{c} / \mathrm{s}$, sinusoidal mains supply was connected to a variable autotransformer feeding a step-up transformer $220 / 1,000 \mathrm{~V}$. Switches were provided to operate the shock marker on the drum, to transfer the connexions to the E.C.G. after the shock and to the defibrillating electrodes (Fig. 1). Since the biological effects of the alternating current depend on the current value and on the shock duration, these formed the independent variables in this investigation.

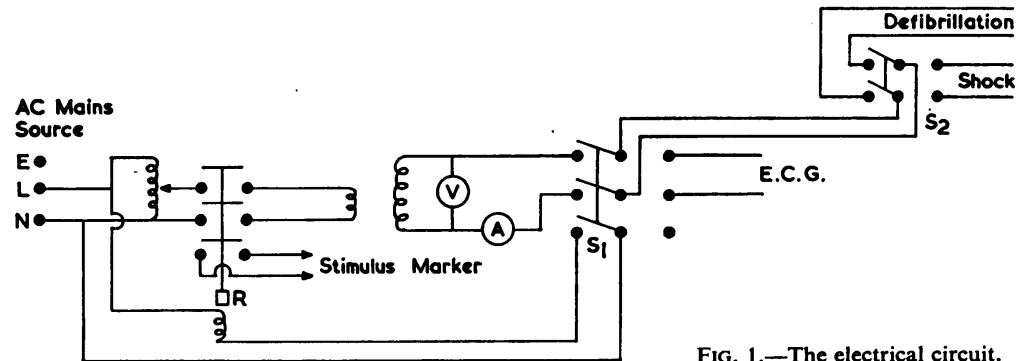

Fig. 1.-The electrical circuit. 
The waveform of the current passing through an animal was checked on an oscilloscope and found to be sinusoidal. In consequence the ammeter read the true rootmean-square value of the current, which value is quoted in the results.

The phase angle between the shock current and the voltage applied to the animal body was measured with an oscillograph and with a power factor meter. The current was slightly leading on the voltage, the power factor for a warm body being 0.96 to 0.98 measured for the range $20 \mathrm{~mA}$ to $200 \mathrm{~mA}$. The typical animal resistance of a fresh specimen, using the forelimb connexions, was about 1,000 ohms, and this value was used to calculate the voltage needed to pass the required current.

If the shock current was passed for a long time the tissues in its pathway were heated and the resistance decreased. The shock current was kept approximately constant by adjusting the applied voltage.

The shock duration and the current were both limited by the thermal damage that they may produce in an animal. A shock of $1,000 \mathrm{~mA}$ applied for 15 seconds produced severe burns of the forelimbs and fixed them solidly to the thorax. Increase in temperature was measured on several preparations.

The preparation of a specimen for an experiment was lengthy, and to obtain a reasonable number of results it was sometimes possible to apply more than one shock to each animal. If the current was small and the duration of the shock not excessive, the animal returned to the preshock condition within a few minutes. In these cases the results of the further shocks to the same animal can be safely considered as reliable, and it is shown later how little effect previous shocks may have on some aspects of behaviour. If the shock current was large or the shock duration was long, this usually resulted in a decrease in blood pressure and sometimes overheating of the forelimbs. Such an animal had to be treated as a partly damaged specimen, and usually where shocks other than first shocks are described the blood pressure immediately before the shock is quoted as well as the blood pressure recorded before the first shock. For this reason data from damaged preparations were interpreted cautiously.

\section{No Arrest of Respiration}

For currents up to $4.5 \mathrm{~mA}$ the passage of a current had very little effect on the respiration, apart from an initial disturbance shown by deepening of respiration of the first breaths at the start of the shock. The end expiratory level was slightly raised during the first breaths.

There was no disturbance of the respiratory rate. Somewhat greater currents also did not arrest respiration but raised the end expiratory level during the period of the shock. In all cases it reverted to normal immediately at the end of the shock. Figures $2 a$ and $2 b$ illustrate these typical features for smaller and larger currents.

It is possible that the passage of a current small enough merely to stimulate the cutaneous nerve
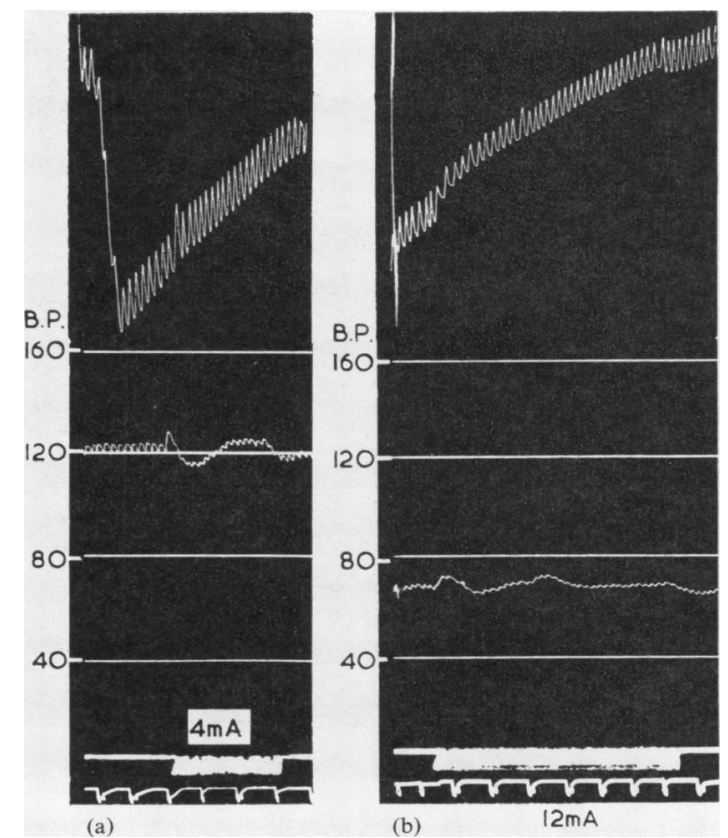

Fig. 2.-Respiration not arrested during shock: (a) $2.9 \mathrm{~kg}$. animal, 6th shock. B.P. before first shock $160 \mathrm{~mm}$. Hg. Shock $4 \mathrm{~mA}$ for 15 sec.; (b) $2.9 \mathrm{~kg}$. animal, 27th shock. B.P. before first shock $160 \mathrm{~mm}$. Hg. Shock $12 \mathrm{~mA}$ for $35 \mathrm{sec}$.

endings might be responsible for the reflex sigh or gasp when the current is switched on. Increasing the current should produce muscular contraction, and observations showed this to be the case.

The raised end expiratory level suggests an increase in the functional residual capacity, which is an indication of hyperinflation (Comroe, Forster, Dubois, Briscoe, and Carlsen, 1962). Under the conditions of the present experiments this might be due either to partial obstruction of the airway or to deformity of the thorax. The partial airway obstruction could result from stimulation of the bronchiolar musculature, whereas the deformity of the thorax would be caused by contraction of the diaphragm, alone or together with contraction of the thoracic muscles. No further evidence was produced to decide between these possibilities.

\section{Arrest of Respiration with 'Breakthrough'}

In these experiments the current arrested respiration but, after varying periods of time from the start of the shock, respiratory movements were observed, while the current continued to pass. That is, the muscular actions of respiration appeared to have broken through the muscular contraction resulting from passage of the current. Normal breathing was resumed immediately the shock was discontinued. 


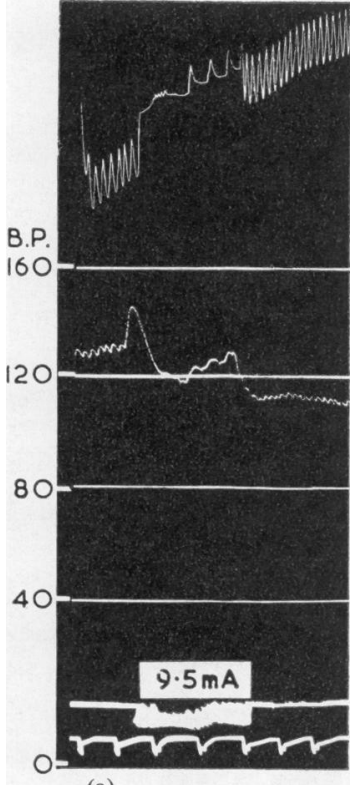

(a)

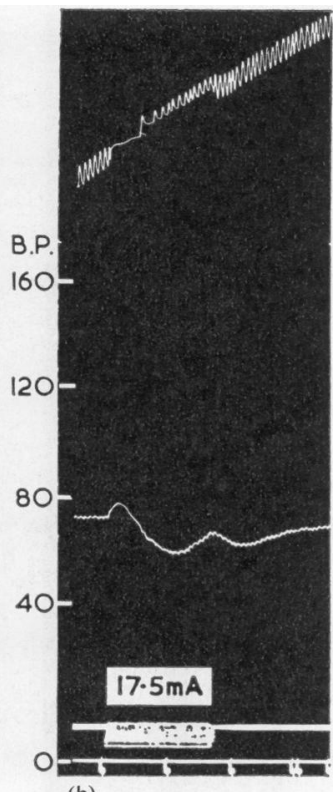

(b)

Fig. 3.-Arrest of respiration with breakthrough: (a) $2.9 \mathrm{~kg}$. animal, 9 th shock. B.P. before first shock $160 \mathrm{~mm}$. $\mathrm{Hg}$. Shock $9 \cdot 5 \mathrm{~mA}$ for $15 \mathrm{sec}$. (The irregularity at the first part of the respiratory tracing is an artefact due to clonic movement of the whole animal.); (b) $2.3 \mathrm{~kg}$. animal, 15 th shock. B.P. before first shock $120 \mathrm{~mm}$. Hg. Shock $17.5 \mathrm{~mA}$ for $15 \mathrm{sec}$.

Figures $3 \mathrm{a}$ and $3 \mathrm{~b}$ illustrate this effect; the range of currents over which it was observed overlapped with the range over which breathing was not arrested.

Time Elapsing before Breakthrough Appeared.There were 38 experiments in which a breakthrough occurred, and the periods elapsing between the start of the shock and the breakthrough are shown in Table 1.

TABLE 1

NUMBER OF BREAKTHROUGHS AT DIFFERENT PERIODS AFTER THE START OF THE SHOCK

\begin{tabular}{c|c|c|c|c|c|c|c|c}
\hline $\begin{array}{c}\text { Time from } \\
\text { start of } \\
\text { shock (sec.) }\end{array}$ & $1-5$ & $6-10$ & $11-15$ & $16-20$ & $21-25$ & $26-30$ & 105 & Total \\
\hline $\begin{array}{c}\text { No. of break- } \\
\text { throughs }\end{array}$ & 15 & 16 & 1 & 0 & 2 & 3 & 1 & 38 \\
\hline
\end{tabular}

Current Values at which Breakthrough Occurred.Respiratory arrest with breakthrough occurred in the current range $7 \mathrm{~mA}$ to $59 \mathrm{~mA}$. The lower figure encroached upon the range over which respiratory arrest did not occur, and the upper figure on the range of currents causing complete respiratory arrest. A study of shocks of increasing current values shows that the greater the current the less was the probability of a breakthrough.

In the current range of $7 \mathrm{~mA}$ to $70 \mathrm{~mA}$ there were 31 shocks lasting 20 seconds or longer, and Table 2 gives the proportions of breakthroughs for different current ranges. Although the numbers are not large, it will be seen that, for shocks of not less than 20 seconds' duration, breakthroughs usually occur for currents up to $40 \mathrm{~mA}$; above that they become less common and do not occur at all above $60 \mathrm{~mA}$.

TABLE 2

PROPORTIONS OF BREAKTHROUGHS AT DIFFERENT CURRENT RANGES FOR SHOCKS LASTING MORE THAN 20 SECONDS

\begin{tabular}{l|c|c|c|c|c|c}
\hline Current range (mA) & $11-20$ & $21-30$ & $31-40$ & $41-50$ & $51-60$ & $61-70$ \\
\hline $\begin{array}{l}\text { Ratio of:- } \\
\text { Shockswithbreakthrough }\end{array}$ & $3 / 3$ & $10 / 10$ & $4 / 4$ & $1 / 5$ & $1 / 4$ & $0 / 5$ \\
\hline \begin{tabular}{l} 
Total number of shocks \\
\hline
\end{tabular}
\end{tabular}

A detailed examination of the results did not indicate that the possibility of a breakthrough occurring depended on the applied shock being a first, second, third, or subsequent shock. In this analysis, shocks of less than 20 seconds' duration were excluded for, although they may appear to be shocks without a breakthrough, one might have occurred had the shock been longer.

Shocks of Long Duration.-The four experiments presented in Table 3 were carried out to find the effects of long shocks with smaller currents. If a breakthrough occurred, the blood pressure remained high and the animal survived (experiment 38 ). If, during one of these shocks, there were only a few respiratory movements accompanied by a low oxygen intake, the blood pressure fell. In one case respiration did not restart after the end of the shock (experiment 51). In this instance, the blood pressure fell precipitously, to below $20 \mathrm{~mm}$. $\mathrm{Hg}$, just before the end of the shock. This, together with the absence of oxygen uptake at that time, was taken to indicate collapse of the circulation, which is therefore regarded as the cause of death.

Comments.-Currents above $7 \mathrm{~mA}$ were capable of arresting respiration. It is known that currents of this order cause sustained muscular contractions in the human subject (Dalziel, Lagen, and Thurston, 1941). It is probable, therefore, that the respiratory arrest is due to contraction of the respiratory muscles. That not all the respiratory muscles are in tetanic contraction is demonstrated by the breakthrough phenomenon which has been observed. This suggests that sometimes the current density is not sufficient to cause tetanic muscular contraction in the whole chest and that respiratory movements may be superimposed. 
TABLE 3

SHOCKS OF LONG DURATION

\begin{tabular}{|c|c|c|c|c|}
\hline Experiment No. & 11 & 38 & 51 & $52 \mathrm{~A}$ \\
\hline Shock parameters & $26 \mathrm{~mA}$ for 150 seconds & $28 \mathrm{~mA}$ for 300 seconds & $45 \mathrm{~mA}$ for 140 seconds & $46-48 \mathrm{~mA}$ for 330 seconds \\
\hline $\begin{array}{l}\text { Consecutive shock no. applied } \\
\text { to the same animal }\end{array}$ & $1 \mathrm{st}$ & 2nd & 3rd & 1st \\
\hline Animal weight (kg.) & $2 \cdot 1$ & $2 \cdot 1$ & $2 \cdot 1$ & $2 \cdot 0$ \\
\hline Record of respiration & $\begin{array}{l}\text { Arrested in inspiration } \\
\text { except for single respi- } \\
\text { ratory movements at } \\
45,105,123,141 \text { sec. } \\
\text { Normal breathing was } \\
\text { resumed immediately } \\
\text { after the shock. }\end{array}$ & $\begin{array}{l}\text { Arrested in inspiration } \\
\text { for the first } 22 \text { sec. } \\
\text { Respiration, resumed } \\
\text { during the shock, is } \\
\text { slow, irregular, and at } \\
\text { a raised end expiratory } \\
\text { level. Normal rate was } \\
\text { resumed immediately } \\
\text { after the shock. }\end{array}$ & $\begin{array}{l}\text { Arrested in marked in- } \\
\text { spiration. Nine single } \\
\text { shallow movements oc- } \\
\text { curred in the interval } \\
32-120 \text { sec. Respira- } \\
\text { tion has not restarted } \\
\text { after the shock. }\end{array}$ & $\begin{array}{l}\text { Arrested in expiration for } \\
\text { the whole of the shock. } \\
\text { After the shock, shallow } \\
\text { respiratory movements } \\
\text { were observed for } 240 \\
\text { sec. then death super- } \\
\text { vened. }\end{array}$ \\
\hline $\begin{array}{l}\text { Blood pressure (mm. Hg): } \\
\text { (a) Before the first shock } \\
\text { (b) Before this shock }\end{array}$ & $\begin{array}{l}135 \\
135\end{array}$ & $\begin{array}{l}135 \\
115\end{array}$ & $\begin{array}{l}135 \\
120\end{array}$ & $\begin{array}{r}120 \\
120\end{array}$ \\
\hline (c) During this shock & $\begin{array}{l}\text { Dropped slowly to } 90 \text { and } \\
\text { to } 70 \text { at } 170 \text { sec., then } \\
\text { recovered to } 130 \text { at } 180 \\
\text { sec. }\end{array}$ & $\begin{array}{l}\text { Remained practically un- } \\
\text { changed. }\end{array}$ & $\begin{array}{l}\text { Changed from } 120 \text { to } 60 \\
\text { within the first } 135 \text { sec. } \\
\text { of the shock and then } \\
\text { dropped sharply to be- } \\
\text { low } 20 \text {, indicating col- } \\
\text { lapse of circulation and } \\
\text { death. }\end{array}$ & $\begin{array}{l}\text { Varied during the shock, } \\
\text { but at the end it reached } \\
30 \text { and after the shock } \\
\text { decreased further to } 20 \text {, } \\
\text { indicating little circula- } \\
\text { tion. }\end{array}$ \\
\hline Remarks & $\begin{array}{l}\text { Oxygen uptake was neg- } \\
\text { ligible. }\end{array}$ & $\begin{array}{l}\text { Oxygen uptake remained } \\
\text { high. }\end{array}$ & $\begin{array}{l}\text { Oxygen uptake was re- } \\
\text { duced during the first } \\
\text { part of the shock and } \\
\text { during the last } 23 \text { sec. } \\
\text { there was none. } \\
\text { Since B.P. collapsed } \\
\text { before the end of shock, } \\
\text { indicating stoppage of } \\
\text { circulation, the lack of } \\
\text { respiration after the } \\
\text { shock has no real sig- } \\
\text { nificance. }\end{array}$ & $\begin{array}{l}\text { Oxygen uptake was very } \\
\text { low. } \\
\text { Respiration was at- } \\
\text { tempted even at the } \\
\text { very low B.P. }\end{array}$ \\
\hline
\end{tabular}

With currents greater than about $40 \mathrm{~mA}$, it seems that the whole thoracic musculature is likely to be in tetanic contraction and no breathing movements are therefore possible. When the tetanic contraction does not include all the thoracic muscles but the current is greater than about $40 \mathrm{~mA}$, the amount of breathing possible is not sufficient to sustain life. It may be questioned why sufficient oxygen is not obtained by aventilatory mass flow (Draper and Whitehead, 1944; Bartlett, Brubach, and Specht, 1959) when breathing is mechanically arrested. Aventilatory mass flow is sufficient to sustain life under basal conditions in the denitrogenated animal. However, under the present experimental conditions, with the thoracic and other muscles in tetanic contraction, their oxygen requirements would be greatly increased. Although the muscles can continue to contract in anaerobic conditions, the available oxygen will be rapidly used up, for contracting muscles may take up to 75 times their basal oxygen requirements (Bazett and Bard, 1956). The two deaths that occurred in this group were associated with a steadily falling blood pressure, a result to be expected from the slowly progressive asphyxia discussed above.

\section{Complete Arrest of Respiration}

This section describes all experiments in which there was a complete arrest of respiration during the shock. In many cases breathing restarted spontaneously after the shock current was discontinued. Whether or not this would occur might depend on the direct results of the shock and be affected by circulatory effects, particularly circulatory arrest. The experiments showing complete arrest of respiration have therefore been divided into three groups having the following features: (a) temporary circulatory arrest present; $(b)$ permanent circulatory arrest present; and (c) no circulatory arrest present.

Ettinger (1933) distinguished in rabbits between ventricular flutter, which frequently spontaneously reverted to normal rhythm, and ventricular fibrillation, which is difficult to change to normal rhythm. Both these conditions lead to death if there is no reversal to normal rhythm. For the purpose of this work there was no point in distinguishing between the two as the point in question was the presence or absence of circulation of the blood.

Temporary Circulatory Arrest.-In these experi- 
ments (see Table 4) there was a fall of blood pressure either during or immediately after the shock; sometimes there was electrocardiographic evidence of ventricular fibrillation. Frequently both effects were observed. However, the decrease in blood pressure was not permanent and usually it rose again very steeply. The fall in blood pressure was probably due

\section{TABLE 4}

COMPLETE RESPIRATORY ARREST WITH TEMPORARY CIRCULATORY ARREST. CASES WITH SPONTANEOUS RESUMPTION OF RESPIRATION

\begin{tabular}{c|c|c|l|c}
\hline $\begin{array}{c}\text { Experi- } \\
\text { ment } \\
\text { No. }\end{array}$ & $\begin{array}{c}\text { Current } \\
(\mathrm{mA})\end{array}$ & $\begin{array}{c}\text { Duration } \\
\text { of Shock } \\
\text { (sec.) }\end{array}$ & $\begin{array}{c}\text { Evidence for Return } \\
\text { of Circulation }\end{array}$ & $\begin{array}{c}\text { Delay in } \\
\text { Respira- } \\
\text { tion (sec.) }\end{array}$ \\
\cline { 1 - 3 } 74 & $71-75$ & 30 & C.R.O.* & 85 \\
78 & 86 & 25 & B.P. & 0 \\
81 & 100 & 15 & B.P. & 4 \\
82 & 120 & 35 & B.P./E.C.G. late & 10 \\
83 & 150 & 35 & E.C.G./B.P. & 38 \\
91 & 280 & 8 & B.P. & 0 \\
94 & $260-380$ & 30 & E.C.G. & $9 / 56$ \\
96 & 360 & 18 & B.P. & 22 \\
97 & $350-390$ & 60 & B.P./E.C.G. late & 60 \\
99 & $330-440$ & 45 & B.P./E.C.G. late & 48 \\
100 & $350-480$ & 30 & B.P./E.C.G. late & 35 \\
102 & $410-430$ & 9 & B.P. & 13 \\
107 & $500-560$ & 15 & B.P. & 20 \\
110 & $550-630$ & 8 & B.P. & 2 \\
111 & 600 & 5 & B.P. & 12 \\
112 & 600 & 5 & B.P. & 10 \\
113 & $500-700$ & 45 & B.P./E.C.G. & 35 \\
116 & 700 & 5 & B.P. & 0 \\
119 & 900 & 5 & B.P. & 3 \\
125 & 1,000 & 25 & B.P./E.C.G. late & 40 \\
\hline
\end{tabular}

*Cathode ray oscilloscope.

to ventricular fibrillation, in which case it is usually a steep fall. However, in five experiments $(83,88$, $105,108,109)$ the blood pressure fell somewhat more slowly and it is necessary to discuss this effect.

It is possible that the slower fall of blood pressure seen in these experiments was caused by the intense muscular contractions kinking the cannula in the artery. The constriction so formed was insufficient to cause complete blockage but enough to slow the rate of fall of pressure in the recording system if the circulation was arrested. Thus when a cannula, completely blocked during the shock, was released at the end of the shock (three cases) the blood pres- sure fell quite sharply. Certainly even the somewhat slower falls discussed here (experiments 83, 88, 105,108 and 109) were much faster than the anoxic fall in blood pressure seen in experiment 51 .

A second explanation of the slow fall in blood pressure would be that it is the result of a decreased venous return resulting from muscular contraction obstructing the flow of blood in the venae cavae. Such an effect would also result in a decreased oxygen uptake.

Thirdly, it is possible that a rise in the peripheral resistance occurring at about the same time as the ventricular fibrillation (that is, early in the shock) would be responsible for the blood pressure falling more slowly.

Ventricular fibrillation was demonstrated by E.C.G. records in seven cases and by observation on the cathode ray oscilloscope in one other case. In six other cases the rise in blood pressure occurred before the E.C.G. was recording after the shock, and this record, when started, showed normal rhythm. In the remaining 12 cases no E.C.G. record was taken. In these last two groups (18 cases) the diagnosis of circulatory arrest and resumption is made on the blood pressure record. This gives a total of 26 experiments in this group in which the currents used varied from $71 \mathrm{~mA}$ to $1,000 \mathrm{~mA}$. In the seven cases in which ventricular fibrillation was demonstrated by E.C.G., a reversion to normal rhythm was also seen, but in four of them (experiments 89, 104, 106 and 109) the blood pressure did not rise and the circulation was consequently not restored. Nevertheless it is more convenient to consider these cases at this stage.

Experiment 94 (Fig. 4) illustrates the type of result grouped in this section. Respiration was completely arrested during the shock. (Irregularities in the respiratory tracing are due to the whole animal movement resulting from the shock.) Two seconds after the shock spontaneous respiration started, but there were only four breaths over a period of 22 seconds. These were followed by an apnoeic period

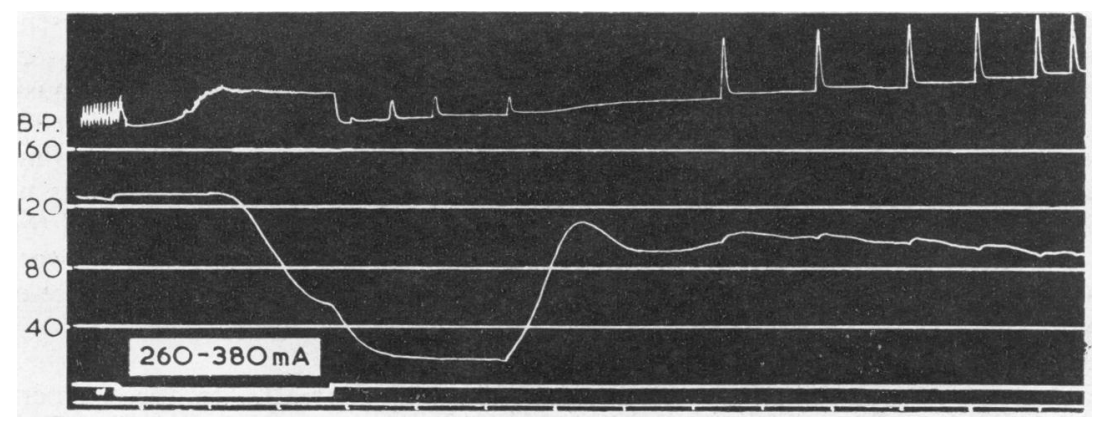

FIG. 4.-Respiratory arrest with temporary circulatory arrest: $2 \cdot 7 \mathrm{~kg}$.
animal, first shock. Shock $260-380 \mathrm{~mA}$ for $30 \mathrm{sec}$. 
of 32 seconds before respiration restarted spontaneously. The blood pressure trace shows a fall 13 seconds after the start of the shock. It remained low (below $20 \mathrm{~mm}$. $\mathrm{Hg}$ ) until 25 seconds after the end of the shock, when it rose rapidly, the E.C.G. clearly showing reversion to normal rhythm.

Experiments which resulted in immediate death and which had common features were 89, 104, 106, and 109 (Table 5). Respiration was arrested com-

TABLE 5

COMPLETE RESPIRATORY ARREST WITH TEMPORARY CIRCULATORY ARREST. CASES WITH NO SPONTANEOUS RESUMPTION OF RESPIRATION

\begin{tabular}{|c|c|c|c|c|c|}
\hline $\begin{array}{c}\text { Experi- } \\
\text { ment } \\
\text { No. }\end{array}$ & $\begin{array}{c}\text { Shock } \\
\text { No. }\end{array}$ & $\underset{(\mathrm{mA})}{\text { Current }}$ & $\begin{array}{l}\text { Dura- } \\
\text { tion of } \\
\text { Shock } \\
\text { (sec.) }\end{array}$ & $\begin{array}{c}\text { Evidence for } \\
\text { Return of } \\
\text { Circulation }\end{array}$ & Defibrillation \\
\hline $\begin{array}{l}88 \\
89\end{array}$ & $\begin{array}{l}1 \\
1\end{array}$ & $\begin{array}{l}225-250 \\
230-240\end{array}$ & $\begin{array}{l}20 \\
60\end{array}$ & $\begin{array}{l}\text { B.P. } \\
\text { E.C.G. }\end{array}$ & $\begin{array}{l}\text { Spontaneous } \\
\text { Open chest } \\
\text { massage }\end{array}$ \\
\hline $\begin{array}{l}104 \\
106 \\
108 \\
109\end{array}$ & $\begin{array}{l}1 \\
6 \\
1 \\
2\end{array}$ & $\begin{array}{c}500 \\
500 \\
500-600 \\
550-600\end{array}$ & $\begin{array}{l}75 \\
75 \\
60 \\
60\end{array}$ & $\begin{array}{l}\text { E.C.G. } \\
\text { E.C.G. } \\
\text { B.P./E.C.G. late } \\
\text { E.C.G. }\end{array}$ & $\begin{array}{l}\text { massage } \\
\text { Electrical } \\
\text { Electrical } \\
\text { Spontaneous } \\
\text { Open chest } \\
\text { massage }\end{array}$ \\
\hline
\end{tabular}

pletely during and after the shock, which lasted 60 or 75 seconds. It has been shown by Schmidt (1956) that cats deprived of oxygen died in about 100 seconds. As noted earlier, aventilatory mass flow, while supporting life under basal conditions, would clearly be insufficient to supply the contracting muscles, which may take up to 75 times their basal oxygen requirements, so that the time quoted by Schmidt will be considerably shortened. All the shocks, apart from experiment 88 , cited in Table 5 were not followed by spontaneous respiration and all apart from experiment 88 involved shocks of 60 seconds or longer.

It was observed in experiments $89,104,106$, and 109 that the blood pressure fell sharply and did not rise again. It follows that in these cases death was due either to ventricular fibrillation or, where defibrillation was successful, to asphyxia, having reached a stage in which circulation could not be restored. In experiments 88 and 108 there was no oxygen uptake after the shock, possibly the result of blockage of the airway.

This was confirmed in experiment 108 by the observation of attempted respiratory movements which were not recorded by the spirometer. This blockage was probably the cause of death because oxygen uptake is to be expected even without respiratory movements if circulation is present.

In experiments $83,97,112$, and 125 death occurred a few minutes after the current ceased to flow, but the four animals started to breathe again within one minute after the shock.
Permanent Circulatory Arrest.-In the 10 experiments grouped in Table 6 permanent circulatory arrest was presumed from the blood pressure trace. and in three cases this was confirmed by E.C.G.

TABLE 6

COMPLETE RESPIRATORY ARREST WITH PERMANENT CIRCULATORY ARREST

\begin{tabular}{c|c|c|c|c|c}
\hline $\begin{array}{c}\text { Experi- } \\
\text { ment } \\
\text { No. }\end{array}$ & $\begin{array}{c}\text { Current } \\
(\mathrm{mA})\end{array}$ & $\begin{array}{c}\text { Dura- } \\
\text { tion of } \\
\text { Shock } \\
\text { (sec.) }\end{array}$ & $\begin{array}{c}\text { Spontane- } \\
\text { ous } \\
\text { Resump- } \\
\text { tion of } \\
\text { Respira- } \\
\text { tion }\end{array}$ & $\begin{array}{c}\text { Delay in } \\
\text { Resumption of } \\
\text { Respiration } \\
\text { (sec.) }\end{array}$ & $\begin{array}{c}\text { B.P. } \\
\text { before this } \\
\text { Shock and } \\
\text { before First } \\
\text { Shock } \\
\text { (mm. Hg) }\end{array}$ \\
\hline 18 & $12 \cdot 5$ & 75 & Yes & 0 & $35 / 130$ \\
71 & 64 & 15 & Yes & 0 & $75 / 120$ \\
77 & $83-87$ & 35 & Yes & 0 & $80 / 160$ \\
80 & 91 & 36 & No & No respiration & $90 / 160$ \\
90 & $250-295$ & 25 & No & No respiration & $150 / 150$ \\
101 & $350-480$ & 60 & No & No respiration & $35 / 125$ \\
103 & $450-550$ & 35 & No & No respiration & $55 / 155$ \\
105 & 500 & 75 & No & No respiration & $110 / 110$ \\
118 & $700-800$ & 5 & Yes & No & $45 / 130$ \\
120 & $900-950$ & 40 & No & No respiration & $150 / 150$ \\
\hline
\end{tabular}

In four experiments $(18,71,77$, and 118) there was a spontaneous resumption of respiration lasting from 12 to 55 seconds after the shock. Experiment 77 (Fig. 5) illustrates a typical result in this group. In all these four experiments the blood pressure fell, by the end of the shock to $20 \mathrm{~mm}$. $\mathrm{Hg}$ or lower, and did not recover. Thus in these four cases death was not caused by the direct effect of the shock on respiration but by failure of circulation.

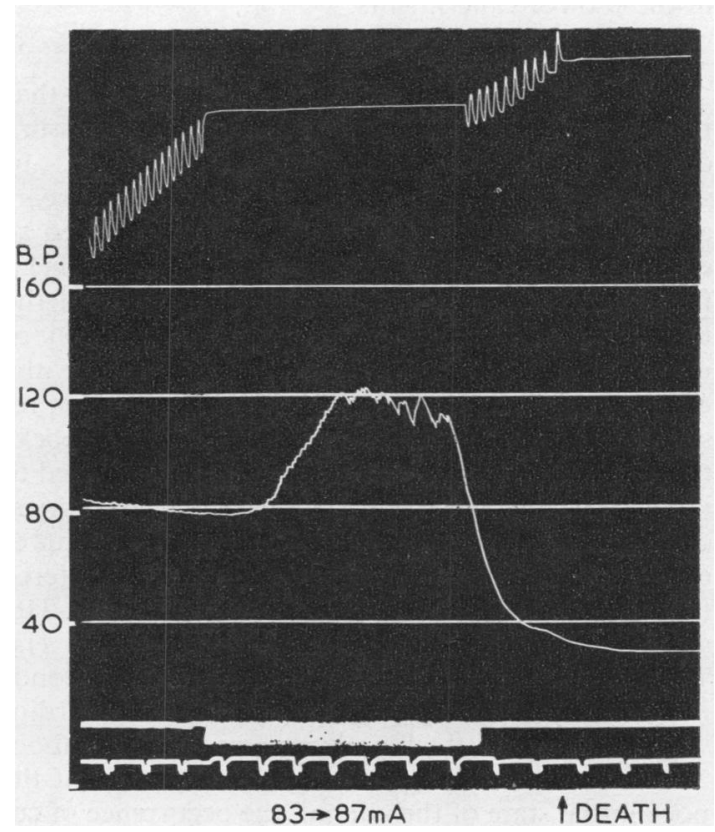

FIG. 5.-Respiratory arrest with permanent circulatory arrest: $2.9 \mathrm{~kg}$ animal, 33rd shock. B.P. before first shock $160 \mathrm{~mm}$. Hg. Shock 83-87 $\mathrm{mA}$ for $35 \mathrm{sec}$. 


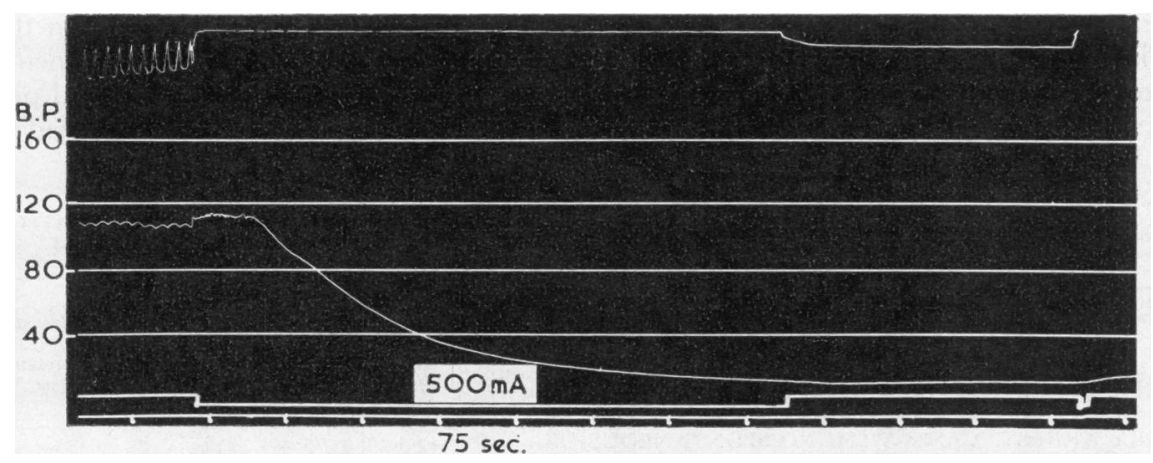

FIG. 6.-Respiratory arrest with permanent circulatory arrest: $3.0 \mathrm{~kg}$. animal, first shock. Shock $500 \mathrm{~mA}$ for $75 \mathrm{sec}$.

In experiments 101, 105, and 120, ventricular fibrillation was recorded by E.C.G., and this explained the fall in blood pressure. Experiment 105 from this group is shown in Figure 6. The range of currents used and the long duration of these three shocks suggest the possibility of asphyxia already discussed.

In the remaining three experiments $(80,90$, and 103), no E.C.G. record was taken, but the fall in the blood pressure trace was similar to that observed in the three previous cases in which ventricular fibrillation was confirmed. Thus it is reasonable to conclude that circulatory arrest was the cause of death in these three experiments.

No Circulatory Arrest.-It was presumed that there was no circulatory arrest if the blood pressure did not fall sharply during or after the shock. In some cases an E.C.G. indicated co-ordinated heart action, although this finding alone was not used as evidence of circulation. The shock currents ranged from $24 \mathrm{~mA}$ to $1,000 \mathrm{~mA}$. Table 7 shows all the results in this group, and, with the exception of experiment 114, all the animals started to breathe again without any external help. The respiration restarted spontaneously immediately after the shock; there was, however, some delay in cases subjected to larger currents. Figure 7 illustrates a typical example from this group. Experiment 114 requires explanation. It was the second shock administered to an animal with a blood pressure of $60 \mathrm{~mm}$. $\mathrm{Hg}$, whereas before the first shock it was $130 \mathrm{~mm}$. Hg. There were four coordinate respirations in 17 seconds immediately after the shock. There was also cardiovascular collapse, the blood pressure falling to about $25 \mathrm{~mm}$. before respiration stopped. In view of the poor initial state of the animal, the occurrence of coordinate respirations immediately after the shock, and the profound cardiovascular collapse, it is felt
TABLE 7

COMPLETE RESPIRATORY ARREST WITHOUT CIRCULATORY ARREST

\begin{tabular}{c|c|c}
\hline Experiment No. & $\begin{array}{c}\text { Current } \\
(\mathrm{mA})\end{array}$ & $\begin{array}{c}\text { Duration of Shock } \\
\text { (sec.) }\end{array}$ \\
\hline 29 & 24 & 15 \\
43 & 35 & 15 \\
52 & 46 & 45 \\
57 & $44-49$ & 35 \\
58 & 50 & 15 \\
59 & 53 & 15 \\
62 & 53 & 45 \\
61 & $53-55$ & 35 \\
64 & 59 & 15 \\
67 & 61 & 15 \\
68 & $60-62$ & 35 \\
69 & $60-62$ & 45 \\
70 & 62 & 45 \\
72 & 65 & 35 \\
73 & 68 & 25 \\
75 & 78 & 25 \\
76 & 85 & 15 \\
79 & 88 & 41 \\
84 & 180 & 10 \\
85 & 200 & 10 \\
86 & 240 & 5 \\
92 & 300 & 5 \\
114 & $600-700$ & 5 \\
122 & $900-1000$ & 9 \\
121 & 950 & 40 \\
124 & 1000 & 15 \\
\hline
\end{tabular}

*Required artificial respiration.

that this result cannot be taken as evidence of primary respiratory failure after a shock.

Comments.- Nearly all the animals in the experiments in which there was no circulatory arrest or in which there was spontaneous recovery in circulation survived the shock.

The cases leading to death may be classified as follows: (a) damaged specimen, partly asphyxiated before the experiment (experiment 114); (b) nine cases where asphyxia was very likely due to the length of the shock (experiments 101, 105, 120, 89, 97, 104, 106, 108, 109); (c) eight cases where a temporary or permanent circulatory arrest occurred with resumption of respiration (experiments 18, 71, 


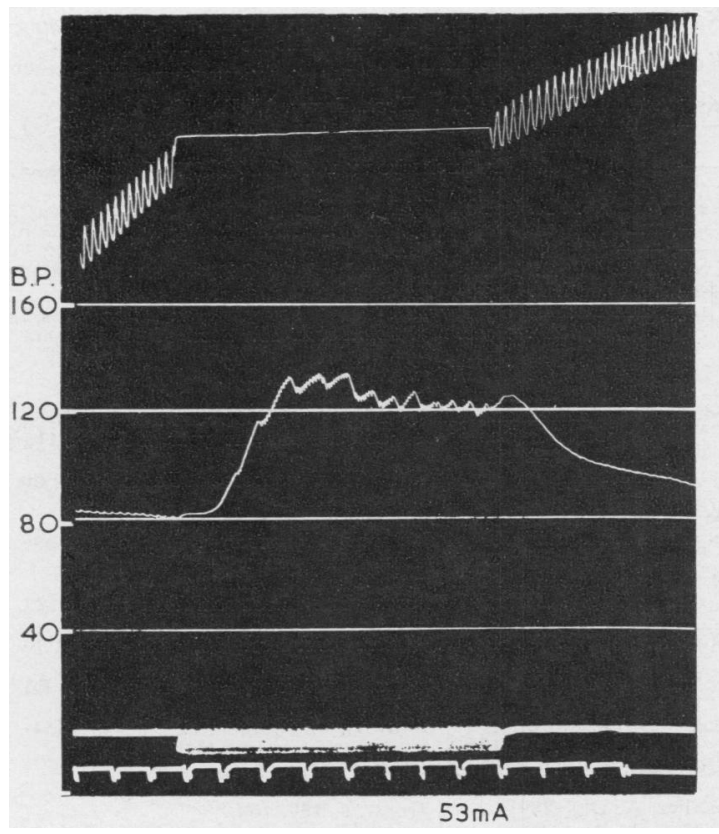

Fig. 7.-Respiratory arrest with no circulatory arrest: $2 \cdot 9$ kg. animal, 31 st shock. B.P. before first shock $160 \mathrm{~mm}$. Hg. Shock $53 \mathrm{~mA}$ for $45 \mathrm{sec}$.

$77,118,83,88,112,125) ;(d)$ four cases where both conditions leading to death were observed together, i.e. arrest of circulation and arrest of respiration (experiments 80,90,103, and 120).

It might be that some of the experiments classified under $(c)$ or $(d)$ belong to $(b)$; they have been classified separately because of the likelihood of other mechanisms, e.g. of ventricular fibrillation or failure of circulation not associated with ventricular fibrillation, being primarily responsible for death.

Thus the possibility of death due to arrest of respiration after the shock arises only from experiments quoted in group $(d)$. This possibility is unlikely because animals to which similar shocks had been applied and which had not developed circulatory arrest or had recovered from it did not develop respiratory arrest. The respiratory arrest, as expected, appears therefore as a consequence of the circulatory arrest. Also in several cases respiration was resumed after a recovery in circulation, e.g. experiments 83 and 94 . It was observed, however, that electric shock sometimes produces a delay in resumption of respiration, and this will be discussed in a subsequent paper.

\section{Conclusions}

The effects observed were very dependent on the experimental conditions, and the more important of these conditions are now restated. The current range was 0 to $1,000 \mathrm{~mA}$ and the shock duration 5 to 300 seconds. The shock was applied from forelimb to forelimb. Rabbits were anaesthetized with sodium pentobarbital.

At currents below $4.5 \mathrm{~mA}$ the respiration was only slightly affected with some disturbance in the first few breaths. Currents of from $5 \mathrm{~mA}$ to $12 \mathrm{~mA}$ did not always arrest respiration but raised the end expiratory level during the shock.

Arrest of respiration, usually of shorter duration than the shock, was observed in the current range $7 \mathrm{~mA}$ to $59 \mathrm{~mA}$. The smaller currents arrested respiration for only a short time. Respiration was resumed, often in a very irregular way, during the shock. In these conditions the animal could survive even very long shocks. For the range $41 \mathrm{~mA}$ to $59 \mathrm{~mA}$ a breakthrough was exceptional. This temporary arrest of respiration may be explained by tetanic contraction of the thoracic muscles, and the breakthrough by the increased carbon dioxide content in the blood leading to increased activity of some respiratory muscles which overcome the muscles in tetanic contractions.

The arrest of respiration started at about $7 \mathrm{~mA}$, which is of the same order as the 'let-go' currents for a human subject.

Complete arrest of respiration throughout the shock was generally observed with currents greater than about $50 \mathrm{~mA}$, and, if the electrical charge passed through the animal was large, respiration started again some seconds after the current was stopped.

When death ensued it could reasonably be explained by asphyxia produced during the shock or arrest of circulation or both without necessarily postulating primary arrest of respiration as a direct cause of death. If the circulation was not affected all the fresh specimens survived shocks even of relatively long duration.

The most important finding was that respiration started again spontaneously, even after shocks in which relatively large amounts of heat were dissipated in the animal. Despite marked macroscopic and histological changes found in the muscles conducting large currents (Lee, 1963), the animals breathed again spontaneously. Obviously confirmation of the results using different anaesthetics and in other species is desirable, and this work is in progress.

Care is needed in relating these findings to electric shocks in humans. Nevertheless, as was mentioned in the introduction, it is reasonable to suppose that respiratory effects in humans caused by electric shock would be similar although the thresholds may be different and are unknown. 
The authors would like to thank Professor W. Schlapp of the Department of Physiology, University of Manchester, for providing facilities for the work to be carried out, and Dr. F. B. Beswick for advice in experimental techniques. The Department of Medical Illustration, Manchester Royal Infirmary, kindly prepared the photographs of experimental records.

\section{REFERENCES}

Ajello, G. (1929). J. industr. Hyg., 11, Abstracts, p. 100 Andreuzzi, P. (1959a). Folia med. (Napoli), 42, 543.

- (1959b). Ibid., 42, 631.

Bartlett, R. G., Jr., Brubach, H. F., and Specht, H. (1959). J. appl. Physiol., 14, 97.

Bazett, H. C., and Bard, P. (1956). In Medical Physiology, 10th ed., ed. P. Bard, p. 238. Mosby, St. Louis.

Boruttau, H. (1918). Quoted by Legge, T. M., et al. (1921).

Comroe, J H., Forster R. E Dubois A B Briscoe, $\dot{\text { A }}$ and Carlsen, E. (1962). The Lung, 2nd ed., p. 21. Year Book Medical Publ., Chicago.

Dalziel, C. F., Lagen, J. B., and Thurston, J. L. (1941). Elec. Engng. (N.Y.), 60, 1073 .

Draper, W. B., and Whitehead, R. W. (1944). Anesthesiology, 5, 262.

Drinker, P. (1928). J. industr. Hyg., 10, 117.

Einthoven, W., Fahr, G., and de Waart, A. (1913). Pflügers Arch. ges. Physiol., 150, 275.

Ettinger, G. H. (1933). Amer. J. Physiol., 105, 457.

Fleming, G. W. T. H., Golla, F. L., and Walter, W. G. (1939). Lancet, 2, 1353.

Greenberg, A. W. (1940). J. industr. Hyg., 22, 104.

Helpern, M., and Strassmann, G. (1941). Amer. J. Path. 17, 592.

Jellinek, S. (1912). Proc. roy. Soc. Med., 6, Electro-Therapeutical Section, p. 17.

Jex-Blake, A. J. (1913). Brit. med. J., $i, 425,492,548,601$.
Kalinowsky, L. B. (1959). In American Handbook of Psychiatry, Vol. 2, p. 1504. Ed. S. Arieti. Basic Books, New York.

Koeppen, S. (1961). EARM/1961/D9, p. 64. International Labour Office, Geneva.

Kouwenhoven,W. B. (1949). Elect. Engng. (N. Y.), 68, 199.

-, Hooker, D. R., and Langworthy, O. R. (1932). Amer. J. Physiol, 100, 344.

- Jude, J. R., and Knickerbocker, G. G. (1960). J. Amer. med. Ass., 173, 1064

Langworthy, O. R. (1930), Ibid., 95, 107.

- and Kouwenhoven, W. B. (1930), J. industr. Hyg., 12, 31.

(1931) Ibid, 13, 145 .

Lee, 'W. R. (1961). Brit. J. industr. Med., 18, 260.

1963). M.D. Thesis, University of London.

Legge, T. M., Ram, S., Levy, A. G., Spilsbury, B., and MacWilliam, J. A. (1921). Proc, roy. Soc. Med., 15. Sect. of Electrotherapeutics, pp. 45-49.

Maclachlan, W. (1930). J. industr. Hyg., 12, 291.

- (1959). Canad. med. Assoc. J., 80, 210.

Ministry of Labour and National Service (1955). Annual Report of the Chief Inspector of Factories for the year 1954, p. 115 H.M.S.O., London.

(1958). Annual Report of the Chief Inspector of Factories for the year 1956, p. 56. H.M.S.O., London.

Morikawa, S., and Steichen, F. (1960). Anesthesiology, 21, 223

Nahum, L. H.' (1955). In A Textbook of Physiology. 17th ed., p. 636 Éd. J. F. Fulton. Saunders, Philadelphia.

Polson, C. J. (1959). Med. leg. J.'(Camb.), 27, 121.

Pozzi, L. (1961). Basic Principles in Vector Electrocardiography, p. 123 Kimpton, London.

Robinovitch, L. (1911). J. Amer. med. Ass., 56, 478, quoted by Greenberg, A. W. (1940).

Schmidt, C. F. (1956). In Medical Physiology, 10th ed., p. 440. Ed. P. Bard. Kimpton, London.

Schwan, H. P., Kay, C. F., Bothwell, P. T., and Foltz, E. L. (1954). Fed. Proc., 13, 131

Urquhart, R. W.'I. (1927). J. industr. Hyg., 9, 140

, and Noble, E. C. (1929). Ibid., 11, 154 .

Waller, A. D. (1889). Phil. Trans., B, 180, 169.

Weeks, A. W., Alexander, L., and Dennis, R. M. (1939). J. industr. Hyg., 21, 517. 